\title{
Absent on Absenteeism: Academic Silence on Student Absenteeism in Canadian Education
}

\author{
Anton Birioukov \\ University of Ottawa
}

\begin{abstract}
Despite mandatory school attendance policies, many students in Canada are frequently absent from school. Absenteeism is linked to numerous negative educational outcomes and is a growing educational issue internationally. This has lead universities in many countries to study the factors associated with absenteeism in order to reduce it. However, the Canadian educational discourse is largely absent on absenteeism. A review of faculty profiles revealed that no Canadian educational scholar investigates absenteeism as their primary area of research. The lack of empirical knowledge concerning student absenteeism is a contributing factor to the high levels of absenteeism evident in Canada. This article serves as a call to action for Canadian academics to research student absenteeism in order to alleviate the behaviour.
\end{abstract}

Keywords: school attendance, student absenteeism, truancy, school refusal, school anxiety, school withdrawal

Canadian Journal of Education / Revue canadienne de l'éducation 44:3 (2021) 


\section{Résumé}

Bien que la fréquentation scolaire soit obligatoire et légalement requise dans chaque province et territoire canadien, de nombreux étudiants sont fréquemment absents de l'école. L'absentéisme est lié à plusieurs mauvais résultats scolaires et constitue un problème croissant à l'échelle internationale. Cela a incité les universités de nombreux pays à étudier les facteurs associés à l'absentéisme afin de le réduire. Cependant, le Canada semble absent des discours éducatifs concernant l'absentéisme scolaire. Un examen des profils des professeurs révèle qu'aucun spécialiste canadien de l'éducation n'étudie l'absentéisme comme principal sujet de recherche. Le manque de connaissances empiriques sur le sujet est un facteur contribuant à l'absentéisme élevé observé au Canada. Cet article lance un appel aux chercheurs canadiens afin qu'ils étudient l'absentéisme des étudiants afin de contribuer à réduire ces comportements.

Mots-clés : fréquentation scolaire, absentéisme, absences des étudiants, abandon scolaire, anxiété à l'école, décrochage 


\section{Introduction}

Every Canadian province and territory has enacted compulsory school attendance legislation stipulating that all school-aged children must attend school on a daily basis (Oreopoulos, 2005). Yet, thousands of kids in Canada are absent from school every day. While exact absenteeism numbers in Canada are not collected, $23.2 \%$ of Canadian students sampled in the 2018 Programme for International Student Assessment (PISA) reported skipping school at least once in the two weeks prior to the assessment (Organisation for Economic Co-operation and Development, 2019). Attendance rates released by the Saskatchewan Ministry of Education (2019) provide similar findings, with 23.9\% of K-12 public school students missing more than $20 \%$ of their classes. This is a troubling development, as absenteeism has been linked with numerous negative outcomes for the absent student, their family and school, and the wider society. Hence, absenteeism is more than simply "skipping school," and has much broader and worrisome repercussions - to which Canada's education-oriented academics have yet to respond.

\section{Literature Review}

Student absenteeism can be defined as a part- or full-day absence from school that is or is not condoned by the student's school and/or family. Absenteeism is caused by many factors, including: the student (e.g., lack of interest in school, health issues), the home (e.g., familial neglect, lack of support in schooling), the school (e.g., poor school climate, unmet educational needs), and society (e.g., poverty) (Reid, 2014). Students often exhibit multiple, interwoven causes for their absenteeism, thereby complicating the absenteeism phenomenon. While occasional absences are expected for many youth during their educational journey, regular absences are detrimental to students' learning, academic performance, and educational achievement (Gentle-Genitty et al., 2019). As students miss classes and/or whole days of school, they miss valuable instructional time, fall behind their peers, and become further disengaged from their schooling (Attwood \& Croll, 2015). Most alarming perhaps is that absenteeism is the dominant precursor to premature school leaving (i.e., dropping out), which has drastic negative implications for a student's future life outcomes (Huber, 2013; Uppal, 2017). Although absenteeism may not cause premature school leaving, it is a signifier of a student's increased disengagement from 
the schooling system. Dropout research has consistently demonstrated that dropping out is not a singular decision, but is rather a slow process of disengagement, which is usually marked by increased absenteeism (Bradley \& Renzulli, 2011; Bridgeland, 2010). Canadian adults without a high school diploma tend to have high rates of unemployment, work in low-paying and precarious occupations, have little to no access to post-secondary education, and be more susceptible to relying on social assistance (Bélanger et al., 2009; Bushnik et al., 2004; Finnie et al., 2015; Gilmore, 2010; Uppal, 2017).

The consequences of student absenteeism are not only confined to the students themselves. The absentee's family also faces repercussions associated with their child's absenteeism, including conflict with the school (Kearney \& Bensaheb, 2006), home visits by school/district personnel (Gase et al., 2015), having to attend parental training (Kearney \& Bensaheb, 2006), and even prosecution for truancy (Fantuzzo et al., 2005; Flaherty et al., 2012). The effects of absenteeism trickle down to the school, as teachers must manage the classroom interruptions that inevitably occur when working with frequently absent students (Gase et al., 2015). In addition, schools must expend considerable resources tracking attendance, and following-up with absent students (Maynard et al., 2017). Lastly, the Canadian state must protect precarious workers through additional expenditures to social assistance programs, and do so with a reduced tax base. Thus, student absenteeism has various negative consequences for numerous actors in Canada.

The severity and far-reaching nature of the repercussions associated with absenteeism has evoked a worldwide response. The causes, consequences, and solutions to absenteeism have been taken up in the international academic literature, including in Africa (Manaze, 2019; Oghuvbu, 2008), Asia (Banerjee et al., 2012; Chou et al., 2006; Seçer \& Ulas, 2020), Europe (Duarte \& Escario, 2006; Mounteney et al., 2010; Strand \& Cedersund, 2013), North America (Gottfried, 2009; Kearney, 2008), and South America (Fischer, 2013; Goodrich et al., 2017). In addition, the International Network for School Attendance (INSA) was established in 2018 to facilitate international dialogue on absenteeism. In the United States, the consequences of absenteeism have become so dire that the United States Department of Education (2019) has referred to absenteeism as a "a hidden educational crisis" (n.p.), and absenteeism has become an important accountability metric under the Every Student Succeeds Act (Hancock et al., 2018). Some Canadian provinces have also sounded the alarm, and released documents urging for the study of absenteeism (Alberta Education, 2014; Office of the Child and Youth Advocate Newfoundland 
and Labrador, 2019; Probe Research, 2009; Saskatchewan Ministry of Education, 2019). Considering that student absenteeism is considered a crisis in many international jurisdictions, there is a paucity of absenteeism-related research being carried out in Canada.

\section{Method}

Determined to investigate the issue further, I began reviewing the faculty profiles of all professors working in Anglophone Faculties of Education in Canada. I identified Anglophone universities that had a Faculty of Education in each province and territory. I then searched the faculty profiles of each Faculty of Education, and sought out academics' publications related to absenteeism. Faculty profiles often include the professor's publication list and/or curriculum vitae. These were read in full, with specific attention paid to absenteeism-related publications. If a publication list was short (i.e., "Selected Publications"), outdated, or not made available, I searched for the scholar's publications using Google Scholar, ResearchGate, and Academia.edu. ${ }^{1}$ Many academics have made their publications widely available on these platforms and their profiles were read in full in search of publications related to student absenteeism. In order to broaden my overall query I also sought out Canadian literature pertaining to absenteeism. I utilized a keyword search, using a combination of student absenteeism and every province/territory, and Canada as a whole (e.g., student absenteeism in Canada, student absenteeism in Ontario, etc.). After this was completed, I performed the same search using synonyms of absenteeism (e.g., school attendance, truancy, school phobia, school refusal, and school anxiety). These searches were done using online library databases which provide access to dozens of educational and multidisciplinary journals. In order to refine the search I specifically looked at publications within the last 25 years. Lastly, I read the titles of all publications in the Canadian Journal of Education from 1995 onward to see if any works were related to student absenteeism.

1 The scope of this study was limited to publications in the English language. I urge French-speaking academics to carry out a similar review. 


\section{Results}

The results are startling and reveal that no Anglophone education-based scholar in Canada studies absenteeism as their primary area of research. ${ }^{2}$ This is not to say that Canada is entirely without absenteeism research, as I was able to locate over 20 recent articles (1995 to present) concerning the topic. However, much of this literature is disjointed, with few of the same authors publishing on absenteeism more than once. Moreover, the majority of the authors are from fields other than education, such as health (French et al., 2013; Glaab et al., 2005; Ward et al., 2019); sports studies (Chard et al., 2020); and family studies (Sanderson et al., 2013). There are some education-based absenteeism studies (Birioukov, 2016; Birioukov-Brant \& Brant-Birioukov, 2019; Carter \& Leschied, 2010; Correia, 1996; Cowans, 2008; Darwich et al., 2012; Vellos \& Vadeboncoeur, 2013); however, few of these research projects studied absenteeism for its own sake (Corville-Smith et al., 1998), instead viewing it as one of many variables (e.g., modifying the scheduling of youth athletic tournaments to minimize absenteeism). Cumulatively, it can be ascertained that there is a considerable lack of Canadian education-based research on absenteeism.

This omission is troubling, particularly as rates of absenteeism appears to be increasing in Canada, while it is declining in other countries. The number of Canadian students reporting skipping school on the Programme for International Student Assessment has grown by 5.4\% between 2015 and 2018 (Organisation for Economic Co-operation and Development, 2018, 2019). During the same period the United Kingdom saw absenteeism drop by $5.6 \%$, and the United States saw a tremendous $18.8 \%$ decline. Both countries now report lower absenteeism rates (UK 18.8\%; US 19.9\%) than Canada (23.2\%). The PISA findings are partially corroborated by the Saskatchewan Ministry of Education (2019), which found absenteeism rates to be stable between 2013 and 2018. Canada's absence in the scholarship is palpable, especially when compared to the United Kingdom and the United States, both of which have a robust scholarly discourse on absenteeism that seeks to understand and mitigate the issue. The results of the aforementioned PISA studies point to Canada's inaction in reducing absenteeism.

2 Dr. Allison Cloth from the Faculty of Education at the University of British Columbia does list "truancy and dropout prevention" as a scholarly interest; however, I could not locate any publications from this academic on the topic. 
Although academics in other countries have prioritized investigating absenteeism, and INSA has been established to bring absenteeism scholars together, this topic has not received much scholarly attention in Canada. The Canadian educational academic discourse is largely silent on student absenteeism, with only a handful of disjointed publications available to guide our understanding of the issue. While we know that almost a quarter of Canadian students are frequently missing school, we know relatively little about why, and what can be done to alleviate the issue. The lack of absenteeism research in the causes, consequences, and possible solutions to absenteeism in Canada limits our understanding of the behaviour and our ability to implement effective interventions to ensure students are attending as much school as they can. The failure to attend to student absenteeism will likely result in the continued lowered educational outcomes for a subset of our students.

\section{Conclusion}

Currently we have a problematic state of affairs, where student absenteeism and the consequent negative outcomes are likely to continue unabated. It is clear that various educational stakeholders must act on the issue. One of the goals of this article is to shed light on the oversight of Canadian academics working in faculties of education to thoroughly study absenteeism. Moreover, I hope this commentary serves as a call to action for scholars concerned with student success to research the causes, consequences, and solutions to student absenteeism.

To begin, we must advocate for the release and wide availability of school attendance records at the district and ministry levels. Without access to this data, it is difficult to ascertain which students are absent and why, which, in turn, creates obstacles for implementing effective and strategic responses to alleviating student absenteeism. Without an overarching Canadian research base, absenteeism interventions currently employed in school districts are haphazard, and rely on US research to inform their practice (Office of the Child and Youth Advocate Newfoundland and Labrador, 2019; Probe Research, 2009). Although US studies are a useful starting point, the socio-political and economic differences between the two countries are significant enough to raise questions as to the transferability of the findings. Moreover, many individual Canadian schools and districts 
are already doing impressive work to decrease and accommodate absenteeism (Birioukov, 2020). These schools and the dedicated staff working within them are an untapped wealth of knowledge. Lastly, it is the absentees themselves that must be listened to. As a whole, absenteeism research has overlooked student voices in its investigations (McKay-Brown \& Birioukov-Brant, 2021). Speaking and listening to the students as to why they are absent, and what can be done to aid them in attending more frequently, should always be the starting point of our interventions. Cumulatively, these are just some starting points, as the field of absenteeism research begins to develop in Canada. I hope that some academics working in Canadian Faculties of Education will heed this call, and begin the necessary work to develop a research base of Canadian absenteeism studies. 


\section{References}

Alberta Education. (2014). Every student counts: Keeping kids in school report. https:// open.alberta.ca/dataset/4aaae9d5-1383-4dcd-b69f-c8c9759a46cd/resource/ c0684d9e-73e5-44c2-a076-88d3ab8ae667/download/6741979-2014-everystudent-counts-keeping-kids-school-report-spring-2014-2014-07-15.pdf

Attwood, G., \& Croll, P. (2015). Truancy and well-being among secondary pupils in England. Education Studies, 31(1-2), 14-28.

Banerjee, R., King, E. M., Orazem, P. F., \& Paterno, E. M. (2012). Student and teacher attendance: The role of shared goods in reducing absenteeism. Economics of Education Review, 31, 563-574.

Barry, A. E., Chaney, B., \& Chaney, J. D. (2011). The impact of truant and alcohol-related behavior on educational aspirations: A study of US high school seniors. Journal of School Health, 81(8), 485-492.

Bélanger, C. H., Akbari, F., \& Madgett, P. J. (2009). Why some youths do not realise their post-secondary education aspirations. Tertiary Education and Management, 15(3), 209-225.

Birioukov, A. (2016). Beyond the excused/unexcused binary: Classifying absenteeism through a voluntary/involuntary absence framework. Educational Review, 68(3), $340-357$.

Birioukov, A. (2020). Attending to absentees: An investigation of how four urban alternative schools respond to student absenteeism [Unpublished doctoral dissertation]. University of Ottawa.

Birioukov-Brant, A., \& Brant-Birioukov, K. (2019). Navigating the ethical dilemmas inherent in enforcing mandatory attendance policies. Frontiers in Education, 4(144). https://doi.org/10.3389/feduc.2019.00144

Bradley, C. L., \& Renzulli, L. A. (2011). The complexity of non-completion: Being pushed or pulled to drop out of high school. Social Forces, 90(2), 521-545.

Bridgeland, J. M. (2010). The new dropout challenge: Bridging gaps among students, parents, and teachers. New Directions for Youth Development, 127, 101-110. 
Bushnik, T., Barr-Telford, L., \& Bussiére, P. (2004). In and out of high school: First results from the second cycle of the Youth in Transition Survey, 2002. Ministry of Industry.

Carter, J., \& Leschied, A. (2010). Maintaining mental health and youth justice-involved students in mainstream education: Implications for Ontario's new mandatory requirement for school attendance. Education \& Law Journal, 19(3), 169-201.

Chard, C., Wigfield, D., \& Potwarka, L. (2020). Innovating youth tournament schedules to minimize school absenteeism: An exploratory study. Sports Innovation Journal, $1,1-17$.

Chou, L. C., Ho, C. Y., Chen, C. Y., \& Chen, W. J. (2006). Truancy and illicit drug use among adolescents surveyed via street outreach. Addictive Behaviours, 31(1), 149-154.

Correia, M. (1996). Sentencing for truancy offenses. Education and Law Journal, 7(2), $173-175$.

Corville-Smith, J., Ryan, B. A., Adams, G. R., \& Dalicandro, T. (1998). Distinguishing absentee students from regular attenders: The combined influence of personal, family, and school factors. Journal of Youth and Adolescence, 27(5), 629-640.

Cowans, J. (2008). Student absenteeism. Education Forum: The Magazine for Secondary School Professionals; Toronto, 34(2), 11-12.

Darwich, L., Hymel, S., \& Waterhouse, T. (2012). School avoidance and substance use among lesbian, gay, transgender, bisexual, and questioning youths: The impact of peer victimization and adult support. Journal of Educational Psychology, 104(2), 381-392.

Duarte, R., \& Escario, J.J. (2006). Alcohol abuse and truancy among Spanish adolescents: A count-data approach. Economics of Education Review, 25(2), 179-187.

Fantuzzo, J., Grim, S., \& Hazan, H. (2005). Project START: An evaluation of a community-wide school-based intervention to reduce truancy. Psychology in the Schools, 42(6), 657-667. 
Finnie, R., Wismer, A., \& Mueller, R. E. (2015). Access and barriers to postsecondary education: Evidence from the Youth in Transition Survey. Canadian Journal of Higher Education, 45(2), 229-262.

Fischer, W. M. (2013). Conditional welfare grants to address truancy and child educational neglect: United States' experiments and Ecuador's mandates. Journal of Law \& Education, 42(2), 275-311.

Flaherty, C. W., Sutphen, R. D., \& Ely, G. E. (2012). Examining substance abuse in truant youths and their caregivers: Implications for truancy intervention. Children $\&$ Schools, 34(4), 201-211.

French, A. E., Tsangaris, E., Barrera, M., Guger, S., Brown, R., Urbach, S., Stephens, D., \& Nathan, P. C. (2013). School attendance in childhood cancer survivors and their siblings. The Journal of Pediatrics, 162(1), 160-165.

Gase, L. N., Butler, K., Kuo, T. (2015). The current state of truancy reduction programs and opportunities for enhancement in Los Angeles County. Children and Youth Services Review, 52, 17-25.

Gentle-Genitty, C., Taylor, J., \& Renguette, C. (2020). A change in the frame: From absenteeism to attendance. Frontiers in Education, 4(161). https://doi. org/10.3389/feduc.2019.00161

Gilmore, J. (2010). Trends in dropout rates and the labour market outcomes for young dropouts. Statistics Canada. https://www150.statcan.gc.ca/n1/pub/81004-x/2010004/article/11339-eng.htm

Glaab, L. A., Brown, R., \& Daneman, D. (2005). School attendance in children with Type 1 diabetes. Diabetic Medicine, 22(4), 421-426.

Goodrich, L. G. W., Castellano, J. M., \& Stefos, E. (2017). An analysis of the social profile of 15 to 17 year old students in Ecuador regarding secondary school attendance and truancy. Review of European Studies, 9(2) 91-105.

Gottfried, M. A. (2009). Excused versus unexcused: How student absences in elementary school affect academic achievement. Educational Evaluation and Policy Analysis, 31(4), 392-415. 
Hancock, K. J., Gottfried, M. A., \& Zubrick, S. R. (2018). Does the reason matter? How student-reported reasons for school absence contribute to differences in achievement outcomes among 14-15 year olds. British Educational Research Journal, 44(1), 141-174.

Heyne, D., Gren-Landell, M., Melvin, G., \& Gentle-Genitty, C. (2019). Differentiation between school attendance problems: Why and how? Cognitive and Behavioural Practice, 26(1), 8-34.

Huber, M. (2013). A narrative account of Robert. In J. D. Clandinin, P. Steeves, \& V. Caine (Eds.), Composing lives in transition: A narrative inquiry into the experiences of early school leavers (pp. 53-72). Emerald Group Publishing Limited.

Kearney, C. A. (2008). An interdisciplinary model of school absenteeism in youth to inform professional practice and public policy. Educational Psychology Review, 20, 257-282.

Kearney, C. A. (2016). Managing school attendance at multiple tiers. Oxford University Press.

Kearney, C. A., \& Bensaheb, A. (2006). School absenteeism and school refusal behavior: A review and suggestions for school-based health professionals. Journal of School Health, 76(1), 3-7.

Manaze, M. (2019). The unheard voice of truant students: Implications for school leaders. Asian Journal of Humanities and Social Studies, 7(4), 123-133.

Maynard, B. R., Vaughn, M. G., Nelson, E. J., Salas-Wright, C. P., Heyne, D. A., \& Kremer, K. P. (2017). Truancy in the United States: Examining temporal trends and correlates by race, age, and gender. Children and Youth Services Review, 81, 188-196.

McKay-Brown, L., \& Birioukov-Brant, A. (2021). Exploring the voices of young people in school absenteeism: What schools need to know. In M.G. Landell (Ed.). School attendance problems: A research update and where to go (pp. 91-98). Jerring Foundation. 
Mounteney, J., Haugland, S., \& Skutle, A. (2010). Truancy, alcohol use and alcoholrelated problems in secondary school pupils in Norway. Health Education Research, 25(6), 945-954.

Office of the Child and Youth Advocate Newfoundland and Labrador. (2019). Chronic absenteeism: When children disappear. https://www.childandyouthadvocate.nf.ca/ pdfs/ChronicAbsenteeismJan2019.pdf

Oghuvbu, E. (2008). Absenteeism and lateness among secondary school students in Nigeria: Profiling causes and solution. Academic Leadership: The Online Journal, 6(3), Article 3. https://scholars.fhsu.edu/alj/vol6/iss3/3

Oreopoulos, P. (2005). Canadian compulsory school laws and their impact on educational attainment and future earnings. Statistics Canada. https://www150. statcan.gc.ca/n1/en/pub/11f0019m/11f0019m2005251-eng.pdf?st=qd5kH0Zc

Organisation for Economic Co-operation and Development. (2018). PISA 2015: Results in focus. https://www.oecd.org/pisa/pisa-2015-results-in-focus.pdf

Organisation for Economic Co-operation and Development. (2019). PISA 2018 results (Vol. II). https://doi.org/10.1787/acd78851-en

Probe Research. (2009). School attendance in Manitoba. Manitoba Education, Citizenship \& Youth. https://www.edu.gov.mb.ca/k12/docs/reports/attendance/ school attendance final.pdf

Reid, K. (2014). An essential guide to managing attendance at your school: Practical resources for all school managers. Routledge.

Sanderson, K., Hutchinson, B., \& Grekul, J. (2013). Exploring the link between school attendance, developmental assets, and social capital in a First Nations community. International Journal of Child, Youth and Family Studies, 4(1), 42-53.

Saskatchewan Ministry of Education. (2019). Annual report for 2018-19. https:// pubsaskdev.blob.core.windows.net

Seçer, I., \& Ulas, S. (2020). The mediator role of academic resilience in the relationship of anxiety sensitivity, social and adaptive functioning, and school refusal with school attachment in high school students. Frontiers in Psychology, 11(557). https://doi.org/10.3389/fpsyg.2020.00557 
Statistics Canada. (2019). Education indicators in Canada: An international perspective. https://www150.statcan.gc.ca/n1/en/pub/81-604-x/81-604-x2019001-eng. pdf?st $=$ vvr9zSUJ

Strand, A. S. M., \& Cedersund, E. (2013). School staff's reflections on truant students: A positioning analysis. Pastoral Care in Education: An International Journal of Personal, Social and Emotional Development, 31(4), 337-353.

United States Department of Education. (2019). Chronic absenteeism in the nation's schools: A hidden educational crisis. https://www2.ed.gov/datastory/ chronicabsenteeism.html

Uppal, S. (2017). Young men and women without a high school diploma. Statistics Canada. https://www150.statcan.gc.ca/n1/pub/75-006-x/2017001/article/14824eng.htm

Vellos, R., \& Vadeboncoeur, J. A. (2013). Alternative and second chance education. In J. Ainsworth (Ed.), Sociology of education, (pp. 36-40). SAGE Publications.

Ward, M. A., Stanley, A., Deeth, L. E., Deardon, R., Feng, Z., \& Trotz-Williams, L. A. (2019). Methods for detecting seasonal influenza epidemics using a school absenteeism surveillance system. BMC Public Health, 19(1232). https://doi. org/10.1186/s12889-019-7521-7

Wood, J. J., Langer, D. A., Clark, S. L., Lynne-Landsman, S. D., Wood, P. A., Eddy, J. M., \& Ialongo, N. (2012). School attendance problems and youth psychopathology: Structural cross-lagged regression models in three longitudinal data sets. Child Development, 83(1), 351-366. 